\title{
To pay more or use less: China's urban water pricing regime and water awareness
}

\author{
$\underline{\text { Zhao B. }}^{\text {a }}$, X. Guo ${ }^{\mathrm{a}}$ and D. Marinova ${ }^{\mathrm{a}}$ \\ ${ }^{a}$ Curtin University Sustainability Policy (CUSP) Institute, Curtin University, Western Australia \\ Email: Baohui.Zhao@postgrad.curtin.edu.au
}

\begin{abstract}
China is the most populous country in the world. Achieving the country's sustainability of water resources is vital for its economic development and social wellbeing. China's shrinking urban water availability has caused worldwide concern for which critics blame the country's poor water management policies. Recently a water price hike has been unanimously suggested by politicians and international bodies to curb urban water consumption. By reviewing urban water pricing practices and analyzing relevant data for Tianjin City, this paper finds that the water pricing regime in China has not proved to be effective for urban water saving. On the contrary, residents and households in China have been under more financial pressure to bear the brunt of the water crisis.

Further problems and challenges associated with water issues and how they impact on China's policies and strategies are also discussed. Most importantly, by establishing a national sustainability strategy model, this paper suggests that water saving publicity and education can play a key role in easing China's water crisis. The findings inform policy makers as to how to deal with China's water shortage while sustaining a quality economic growth.
\end{abstract}

Keywords: per capita water resources availability, water scarcity, water pricing, public hearing, GDP growth model, population, water awareness 


\section{INTRODUCTION}

The sustainable use of China's limited water resource is crucial for its economic prosperity. This paper first explores whether the recent water-pricing regime is an effective measure of curbing China's urban water consumption using the water-thirsty Tianjin as a case study. It then discusses urban water issues and challenges faced by Chinese urban residents. As sustaining China's water usage needs a wide range of water saving publicity and education, a national sustainability strategy model is put forward.

China's per capita water resources availability is estimated at $2,195 \mathrm{~m}^{3}$ and this figure will drop to $1,760 \mathrm{~m}^{3}$ in 2030 when China's population is expected to reach 1.6 billion which is very close to the water-scarcity limit at $1,700 \mathrm{~m}^{3}$ (Wan and Zhou, 2009). Currently China is categorized as one of 13 countries with serious water scarcity as 30\% of its 661 cities are water-scarce (Dow Water \& Process Solutions, 2011). Despite this, from the 1950 s to 2000 agricultural, industrial and domestic water consumption increased 3, 46 and 41 times respectively (MWR, 2002). Water tables are falling but demand is steadily rising. In 2002 fresh water consumed in China reached 549.7 billion $\mathrm{m}^{3}$ or $13 \%$ of the world's total consumption (Zhang and $\mathrm{Xu}, 2008$ ).

Since 1980 a water shortage is spreading across China, impacting its economic development and people's wellbeing. More than 500 large cities experience severe water shortage and the problem is worse in the country's north (Brown, 2003). The links between water shortage and economic losses are yet to be properly analyzed (Li et al., 2010), but it is estimated that more than half of these cities suffered a total of US $\$ 15$ billion industrial production loss or $¥ 200$ billion (Eko-Leder, 2011). The annual loss in grain production reached 20 million tons (Kim, 2008). A large proportion of the existing water resources are polluted.

Climate change is a wildcard for China's water security. The glaciers on the Tibet-Qinghai Plateau are melting at 7\% a year (Brown, 2008). They feed the Yellow River and Yangtze River whose water irrigates the rice and wheat fields of China. If global temperatures get higher, more extreme weather events, including more intense drought can be expected, further lowering the water tables. This is already visible in China. The Yangtze River Basin experienced droughts in 2007, 2209 and 2011. The OECD (2008) states that by 2030 China would have become the largest economy, but it would also be haunted by severe water scarcity.

Maintaining water security is vital for China's national goal of prosperity and wellbeing. Zheng (2003) defines water security as: without exceeding the carrying capacity of water resources, water supply being able to meet the demands of human wellbeing, social progress, economic development and ecosystems. However, given the driving forces of increasing population, rapid urbanization and industrialization, improvement of living standards, level of governance, level of awareness about ecosystems, and most of all rising temperatures as a result of global warming, it remains a daunting task to reverse the current trend of water consumption and tackle the wide-spreading water shortage. China's water crisis, built up over many decades but progressively deteriorating, has become life-threatening (Brown, 2008).

The Chinese government is aware of the problem. A series of laws and regulations at both central and local level regarding water resources have been rolled out and a reform of the management systems has been undertaken. An additional momentum took place in December 2010 when the central government approved for local governments to further raise urban water prices (Central Government of PRC, 2011). This decision intends to have water prices reflect value more accurately. By addressing the demand side of the water scarcity issue, it seems that the government is making a change in the right direction. Is this enough?

\section{URBAN RESIDENTIAL WATER CONSUMPTION}

Urban residential water consumption accounts for $40-70 \%$ of total urban water consumption (Healthy Drinking Water Net, 2011) and Table 1 shows the breakdown of household water consumption. Under the

Table 1. Household water usage breakdown for ten southern China capital cities, 2009

\begin{tabular}{|l|l|l|l|l|}
\hline Usage & $\begin{array}{c}\text { Hygiene } \\
\text { \&Washing }\end{array}$ & Shower & Cooking & Drinking \\
\hline$\%$ & 58.7 & 27.3 & 6.9 & 5.6 \\
\hline
\end{tabular}

Source: Healthy Drinking Water Net (2011) planned economy, urban water service was heavily subsidized as a basic welfare service and was taken for granted. With more cities experiencing water shortages, some started to raise their water prices from the late 1990s. For example, Tianjin raised its water price from $¥ 0.98$ in 1997 to $¥ 2.60$ in 2003 (Liu et al., 2003). China

started to raise the price of water in 2001 (Brown, 2003), twenty years after it first adopted its opening policies, showing the high sensitivity and political difficulty in making such decisions. When exploring water shortages many argue that the unrealistically low water price is one of the major factors. Brown (2003) believes that cheap water results in low efficiency and low productivity; therefore "realistic prices" should be adopted in 
order to encourage efficiency. He noticed that after a public hearing in mid 2004, Beijing raised the water prices for urban and industrial consumers from $¥ 4.01$ (48\&) to $¥ 5.04(61 \notin)$ per $^{3}$ (one kl). The comparison between water prices in China and Australia (see Tables 2 and 3) shows that Chinese urban residents are paying no less for water usage indicating that water price is already high.

Table 2. Water rates comparison two between

Australian States and two Chinese cities

\begin{tabular}{|c|c|c|c|c|c|c|c|c|}
\hline \multirow{3}{*}{\begin{tabular}{|l|} 
Cities \\
Period \\
Rates per $\mathrm{m}^{3}$ \\
\end{tabular}} & NSW & WA & \multicolumn{2}{|c|}{ Tianjin } & \multicolumn{2}{|c|}{ Shanghai } & & \\
\hline & \multicolumn{2}{|c|}{$2008-2009$} & Dec'08 & \multirow{2}{*}{\begin{tabular}{|l|} 
Dec’09 \\
$¥ 3.9$ \\
\end{tabular}} & \multirow{2}{*}{\begin{tabular}{|l|} 
Dec’08 \\
$¥ 1.93$ \\
\end{tabular}} & \multirow{2}{*}{\multicolumn{2}{|c|}{\begin{tabular}{|c|} 
Dec’09 \\
$¥ 2.11$ \\
\end{tabular}}} & \\
\hline & A\$1.96 & A\$1.64 & \begin{tabular}{|l|}
$¥ 3.4$ \\
\end{tabular} & & & & & \\
\hline \multicolumn{9}{|c|}{$\begin{array}{l}\text { Sources: Compiled from China Water Net and the Australian } \\
\text { Bureau of Statistics, } \\
\text { Note: WA-Western Australia; NSW-New South Wales }\end{array}$} \\
\hline \multicolumn{9}{|c|}{ Table 4. Shanghai's commodity prices 2010 (Yuan, source: } \\
\hline Commodity & Old & New & $\infty \%$ & Commodity & & Old & New & $\%$ \\
\hline Petrol 93\#/KL & 5.9 & 6.87 & 16 & Bean Curd So & sup/bowl & 1 & 1.2 & 20 \\
\hline Cable TV/mont & 13 & 23 & 77 & Oil Pancake/e & & 1 & 1.3 & 20 \\
\hline Apar & & & $>30$ & Rice/500g & & 1.2 & $! 2$ & 67 \\
\hline Water/KL & 1.93 & 2.2 & 14 & $\overline{\text { Ginger } / 500 \mathrm{~g}}$ & & 4 & 4.5 & 13 \\
\hline Fried Bun/ea. & 1 & $1.5 \mathrm{r}$ & 50 & Cold Rice No & odle/bowl & 3.5 & 4.5 & 33 \\
\hline Chick & 2.9 & 3.4 & 17 & & & 6 & 12 & 100 \\
\hline Taxi Base & 11 & 12 & 10 & & IRepair & 0.5 & & 300 \\
\hline
\end{tabular}

The rising urban residents' income in China is accompanied by a continuous hiking of prices (see
Table 3. Annual per capita disposable income in Australia and two Chinese cities, 2004

\begin{tabular}{l|l|c|c|}
\hline & Australia & Tianjin & Shanghai \\
\hline Income & A\$ 20,404 & $¥ 11,467$ & $¥ 16,683$ \\
\hline $\begin{array}{l}\text { Water }\left(\mathrm{m}^{3}\right) \text { purchasing } \\
\text { capacity in 2009 prices }\end{array}$ & WA: 12,441 & 2,940 & 7,907 \\
\hline
\end{tabular}

Sources: Compiled from worldsalaries.org and

http://www.stats-tj.gov.cn/Article/tjgb/ (1.8. 2011)

\section{URBAN WATER PRICING IN CHINA}

Urban water pricing in China is distinctive. First, it is a part of an overall price rising (Table 4). Second, it happens everywhere, including cities with higher water availability. Third, the water price hike is in consecutive years in some cities, such as Tianjin and Shanghai in 2008 and 2009 (Table 2) and again in 2010 and 2011. Fourth, the magnitude of rise is substantial, in some cases up to $40 \%$ in one go (Ma et.al., 2009). The introduction of pricing public hearings is expected to help improve China's public participatory system. However, this instrument is fledgling and often turns out to be a 'price-hiking hearing' with its legitimacy and fairness questioned. Some hearings are orchestrated with fake representatives (Wang, 2010), others give participants only 'yes or no, got to rise' proposals (Chinanews, 2010). No evidence on water consumption

Table 5. Household water consumption, Beijing 2007

\begin{tabular}{|c|c|c|c|}
\hline $\begin{array}{c}\text { Household Monthly Income } \\
\text { (Yuan) }\end{array}$ & $500-1000$ & $1000-2000$ & $2000-4000$ \\
\hline Number of households & 24 & 49 & 18 \\
\hline$\leq 10$ tons/month (\%) & $19(79)$ & $36(73)$ & $9(50)$ \\
\hline $10-20$ tons/month (\%) & $4(16.7)$ & $10(20.4)$ & $5(27.8)$ \\
\hline$>20$ tons/month (\%) & $0(0)$ & $2(4.1)$ & $2(11)$ \\
\hline
\end{tabular}

Source: www.5ykj.com/Article/zjbgdcbg/73551.htm (20.7.2011) decline following rising water price is available. It is business as usual (see Table 5). Disadvantaged households are bearing the burden saving water as much as they can and are likely to be more severely impacted in the future. High-income families will continue to use as much water as their lifestyle requires, unless their water awareness improves and behavioral changes take place. On the industry front, water pricing forces managers to improve water efficiency and productivity. However, to avoid paying high water rates, some companies negotiate with local governments their own supply sources continuing to withdraw local water, and some changes are superficial and misleading. The next section analyzes the Tianjin case study.

\section{DISCUSSIONS: CASE STUDY OF TIANJIN}

Figure 1. Tianjin population growth, 2001-2009 (compiled from Tianjin Statistical Information Net, 2011a)

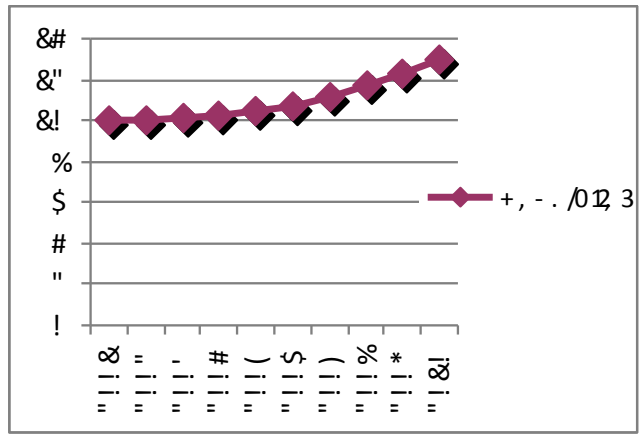

Tianjin is an example of China's expanding population (Figure 1), industrial water demand versus shrinking water resources and supply. Its current population is 13 million with 2.929 million added over the past ten years, an increase of $29 \%$ with annual increase $2.6 \%$ (Tianjin Statistical Information Net, 2011a). In the coming twenty years, economic growth will continue to be a priority for China to alleviate the poverty of its huge population. Tianjin has been designated by the central government as the economic hub for northern China and has gained fast industrial development over the years (see Table 6). It is however one of the most water scarce cities in China. The current per capita water availability is 
about $160 \mathrm{~m}^{3}$ (Miao et al., 2008), about 1/16 of the average per capita water availability in China. The city depends on outsourced water for around a third of its water usage (Sun and Zhang, 2010). Even with water added from the Luan River Water Diversion Project and other places, the per capita availability is only $370 \mathrm{~m}^{3}$ (Ifeng, 2011b), while the world recognized bottom line is $600 \mathrm{~m}^{3}$ (Miao et al., 2008).

Table 6. Major industrial products in Tianjin 2008, 2009, and 2010

\begin{tabular}{|c|c|c|c|c|c|c|c|}
\hline \multirow{2}{*}{ Product } & \multirow{2}{*}{ Unit } & \multicolumn{6}{|c|}{ Gross Production and Increase Rate } \\
\cline { 3 - 8 } & & $\mathbf{2 0 1 0}$ & $\mathbf{\%}$ & $\mathbf{2 0 0 9}$ & $\mathbf{\%}$ & $\mathbf{2 0 0 8}$ & $\mathbf{\%}$ \\
\hline Natural Oil & Million tons & 33.32 & 45.1 & 22.97 & 15 & 19.94 & 3.6 \\
\hline Natural Gas & Billion M & 1.72 & 20.2 & n/a & & 1.40 & 5.0 \\
\hline Power Generation & Billion KWH & 58.91 & 39.7 & n/a & & n/a & \\
\hline Refined Petrol & Million tons & 1.65 & 21.0 & 1.36 & 14.0 & n/a & \\
\hline Ethylene & Million tons & 1.10 & 480 & 0.19 & 11.1 & n/a & \\
\hline Polyester & Million tons & 0.29 & 27.0 & 0.23 & 19.4 & n/a & \\
\hline Chemical Fiber & Million tons & 0.13 & 28.2 & n/a & & n/a & \\
\hline Cement & Million tons & 8.10 & 21.9 & 6.91 & 23.9 & 5.35 & 4.2 \\
\hline Pig-iron & Million tons & 19.26 & 12.8 & 17.6 & 19.9 & 15.20 & 5.7 \\
\hline Crude Steel & Million tons & 21.62 & 11.4 & 21.23 & 24.5 & n/a & \\
\hline Finished Steel & Million tons & 44.84 & 12.8 & 40.41 & 30.5 & 30.07 & 6.8 \\
\hline Seamless Steel Tube & Million tons & 3.48 & 2.3 & 3.25 & -2.2 & 3.32 & 22.2 \\
\hline Automobiles & Million & 0.74 & 22.5 & 0.60 & 11.3 & 0.54 & 18.4 \\
\hline Bicycles & Million & 22.41 & 21.6 & 19.06 & 6.2 & 18.53 & 14.1 \\
\hline Mobile Phones & Million & 91.07 & 7.0 & 85.59 & -5.5 & 90.05 & -8.3 \\
\hline Lithium-ion Batteries & Million & 508 & 8.0 & n/a & & n/a & \\
\hline Semi-conductor ICs & Million & 890 & 38.9 & n/a & & n/a & \\
\hline Electronic Components & Billion & 465.59 & 45.5 & 312.65 & 34.2 & 216.99 & 22.3 \\
\hline Source: Compiled from Tianjin Statistical Information Net $(2011 \mathrm{~b})$ & & \\
\end{tabular}

The newly added three million people are definitely entitled to share the dwindling water for the city. According to Brown (1977), population growth is a 4.1. Expanding water supply double-edged sword: it expands on biological systems and destroys these resources. Once the demand exceeds the carrying capacity of water resources, population growth will only accelerate the deterioration of resources and further shrink the per capita water availability. Many of Tianjin's industries are high-energy intensive and water-thirsty. China's water consumption per $¥ 10,000$ GDP is about $159 \mathrm{~m}^{3}$, 10-20 times higher than in developed nations and water reuse rate in China is $20-30 \%$ compared to $75-85 \%$ in the developed world (Eko-Leder, 2011). China's high GDP growth means high water consumption and waste. Rising water prices alone will not to address the water problem.

Priority is still given to the supply side in addressing the water shortage. Tianjin keeps depleting aquifers and polluting the available water resources. The surface water resources development and exploitation rate in Tianjin now exceeds $76 \%$, far beyond the $40 \%$ tipping point (Eko-Leder, 2011). There is a long history of over-pumping ground water which has resulted in not only depletion of the aquifer but also in the forming of expanding subsidence under Tianjin, leading to up to $2.6 \mathrm{~m}$ falls of the ground. To keep the city functioning, three national-level water-diversion projects have been undertaken, ie the Luanhe River Water Diversion Project (1970s-1980s), the Yellow River Water Diversion Project (1990s) and the US\$ 60 billion South-North River Water Diversion Project (2000s). The latter project covers a larger area than Tianjin, but due to serious contamination and pollution along the channels and rivers of its east branch causing significant delays, the city will start to receive the Yangtze River water only from 2013 (Ifeng, 2011b). In a desperate move, the Tianjin government attempted unsuccessfully to trade water rights with the neighboring Hebei Province. Seawater desalinization is an alternative to address Tianjin's water shortage but the price of the desalinated water is $¥ 8.15 / \mathrm{m}^{3}$ (Ifeng, 2011b), equivalent to US\$1.26 (as of 4.7.2011), comparing to Middle East’s average price of US\$0.53 (Addison, 2005). The current annual water demand in Tianjin is 793 million $\mathrm{m}^{3}$. Despite all efforts, there is still an annual shortage of 337 million $\mathrm{m}^{3}$ (Ren, 2010).

\subsection{Tianjin's water scenarios for 2030}

Scenarios are used by futurists to better understand the ramifications of particular trends (McMahon, 2006).

Given Tianjin's circumstances, a single end forecast would not suffice to show the complexity of the city's water situation. A number of different scenarios (Figure 2) can accomplish this. The year 2030 is set as the target for the four different ends. Uncertainties are trends that are currently very difficult to predict, such as improvements in water resource development, efficiency and productivity, institutional policies, residents' behaviors and impact of global warming. The unchanged parameters include economic growth, population growth, living standards improvement, and so on.

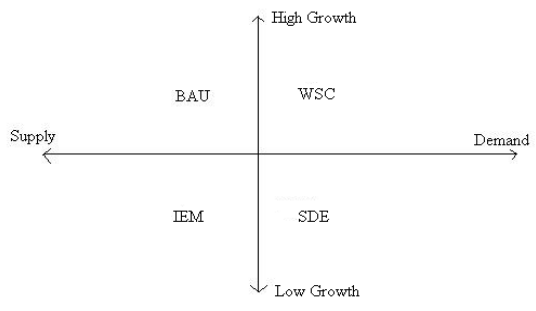

Figure 2. Tianjin water scenarios 2030 
- Scenario 1 BAU (Business as Usual): Major policies on economic growth, natural resources management, population and lifestyle remain unchanged. Tianjin's economy maintains a high growth rate. By 2030 it is home for 22 million, an increase of 9 million from 2010. Water supply is at a higher level; the Yangtze River Water Diversion Project starts to send water to the arid north, including Tianjin. Wells as deep as 1543-1800 m (Zhang and $\mathrm{Xu}, 2008$ ) also ease the water stress in Tianjin. As consumerism prevails, household water efficiency is unchanged. Tianjin's new riches start to build swimming pools in their backyards.

- Scenario 2 IEM (Institutional Expedient Measures): The current economic development, population growth and water resources management approaches continue. In response to water shortage, China still resorts to increasing supply and invests in large capital-intensive hydraulic infrastructure. In 2030 phase 2 of the South-North Water Diversion Project starts providing water to the north. With enough water for the city, Tianjin sends over 500 million $\mathrm{m}^{3}$ water to Hebei when rainfall is good (Zhao, 2009). However, with glaciers in the Tibetan Plateau retreating, the amount of water fed into Yangtze drastically reduces.

- Scenario 3 SDE (Sustainable Development Effort): Water demand reduces due to the restructuring of the growth model and improvement in water awareness. A restructuring of the Chinese economy, shifting from resources-intensive to sustainable industries, takes place. Water efficient industry technologies are widely applied. Water reuse and recycling technologies are used in most residential areas. The whole city draws on the technologies from the Sino-Singapore Tianjin Eco-city (Peng et al, 2011). In 2030, Tianjin's GDP growth drops to one digit lower than China's average. Water demand reduces with signs that zero growth of water demand could be achieved while maintaining economic growth, ecosystems health and human wellbeing.

- Scenario 4 WSC (Water Security Collapse): The trend towards collapse of the Tianjin's water security is irreversible due to over-exploitation of the water resources. Any efficiency achievements are offset by the continuing high demand for water due to population and GDP growth. Severe droughts as a result of global warming impact on China successively, aggravating water shortage. Any IEMs are not effective because the source rivers for water-diversion run dry, revealing the severe consequences of policies made on the wrong assumption for surplus water in Tianjin after the South-North Water Diversion Project (Li et al., 2010). By 2030 the water consumption by Tianjin's 22 million population is huge while the per capita water availability drops to $171 \mathrm{~m}^{3}$. Water supply to industry and households is cut to the lowest level. Many factories close as water demand to keep the minimum operation level is not met. Tall apartment buildings are no longer accessible to water. The share of people without access to safe drinking water and basic sanitation is high.

\subsection{Sustainability-bearable, equitable and viable}

Past miraculous economic growth was supposed to bring prosperity to Chinese people (Jackson, 2009). Instead they are facing a fate of constant water shortages and subsequent consequences, including a possible famine. Expanding water supply is not the answer to Tianjin's water shortages; though tackling the demand side, water pricing is also not an effective instrument. Sustainability is based on a harmony between society, economy and environment. The water pricing system should reflect this to be bearable, equitable and viable.

- First, water prices should be bearable to consumers and water consumption should be bearable to the ecosystem. Chinese urban residents are already paying high water prices. Though water accounts only for a small proportion of total household expenditure, it is one of the many straws on the camel's back. Rijsberman (2000) argues that irrational water pricing leads to rapid diffusion of water efficient technologies and increased capital investment. However in today's China, because of financial and operational constraints, it will take time before industrial consumers reach the water efficiency and productivity level of their foreign counterparts. Irrational high prices will either force them to cut down production capacity, shift to alternative water supplies, which would not reduce the total water consumption at local level, or close their operations. This would impact on China's economic development and drive up unemployment. Imposing a cap on water prices, which does not take away water consumption control, seems like a good idea.

Exceeding the carrying capacity of water resources will lead to the loss of the material basis for development which will destroy ecosystems and degrade the living environment (Zheng, 2003). Raising water prices and privatizing water services would not help China, as the marketplace usually prioritizes short-term economic benefits rather than long-term regional development (Draper, 2006). Therefore, the marketplace is not a reliable way to improve China's long-term water security. The major driving force for China's water crisis is the high population and GDP growth model which leads to the unbearable exploitation of water resources, high water prices and undermines water security. A zero growth water demand model should be put in place, which will not affect ecosystems while maintaining economic growth and the wellbeing of population.

- Second, water pricing should be equitable. Many water pricing public hearings undertaken in China are short of transparency and true public participation. A tiered pricing system that better looks after disadvantaged families is not used in the cities. In an unfair competition environment, private businesses pay high prices for 
water while the state-run companies explore their own water resources and pay lower prices. Water development and consumption should also be equitable between generations and for all ecosystems.

- Third, water pricing in China is not viable in that it is neither yielding expected substantial water efficiency benefits nor reinforcing the goals of the water pricing system. The introduction of this system into China's water resources management was meant to improve water efficiency and productivity, and further by achieving that help address water shortages which might undermine the building of a harmonious society. However, profit-oriented and mismanaged, the water pricing system is doing the opposite. Many local governments that are cash-short, tend to turn to businesses to 'develop, operate and own city water systems' in Whiteford and Whiteford, 2005: 237). Wide-spreading water shortages put China's harmonious society goal in jeopardy and so does the irrational uncapped water price rising across Chinese cities. Therefore, water pricing creates a huge deficit for social capital; it is not viable socially and politically. In addressing water issues, apart from human survival, ecological, spiritual and inter-generational needs should also be met at prices much lower than the currently set market price. Irrational water prices push many Chinese enterprises to the limit. Due to finance and technology constraints, water efficiency and productivity cannot be improved further in a short period of time. Running a business at the current high water prices is often uneconomical. Environmentally, given the current population and economic growth as well as the depletion rate of natural resources, it is not viable for the human race to do 'business as usual' as the collapse of ecosystems leads to social and economic meltdown.

Figure 3. Water pricing and sustainability

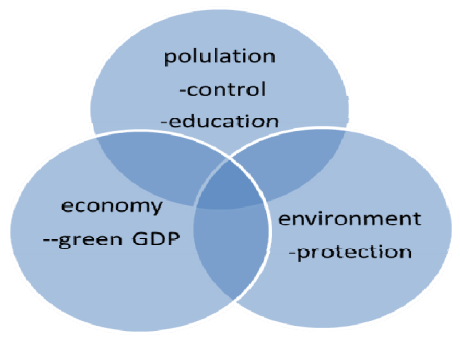

Addressing China's water shortage requires a national sustainability strategy, a systems approach rather than a sporadic and piecemeal sustainability (Healthy Drinking Water Net, 2011). NGOs have been playing a critical role in China's water resource protection. By 2008, there were 3,600 registered independent NGOs, which have been carrying out a large number of activities to promote water education in China (The Asia Water Project: China, 2011).

\section{CONCLUSION AND RECOMMENDATIONS}

A water crisis in China is being experienced by the current and passed to future generations. There is no sign of any slowdown in unsustainable water consumption. Chinese cities need safe and adequate water supply. Under the scenarios developed in this study, the current approach fails to provide a balance between water demand and supply. While addressing the demand side, the water authorities have mainly focused on raising water prices but any possible gains from improving water productivity and efficiency are offset by expanding consumption under the current growth model. Lack of full public participation, transparency and supervision in the process of water price setting substantially waters down this instrument. Water pricing should progress in sequence and take into account the principles of sustainability to help build a harmonious society in China. A water crisis, as one of the many challenges built up in the last five decades, may be the one that has a fatal impact. It is not a matter of paying more or less for water, but rather maintain a sustainable consumption. This can only be achieved by overhauling the current GDP growth model, stabilizing population growth and improving the water awareness of every single Chinese, rich or poor, disadvantaged or powerful.

\section{ACKNOWLEDGEMENT}

The last three authors acknowledge the financial help of the Australian Research Council.

\section{REFERENCES}

Addison, E. (2005) Political effluent: Implementing wastewater re-use in Wadi Musa, Jordan, Aridlands Newsletter, 57, http://ag.arizona.edu/OALS/ALN/aln57/addison.html (25.7.2011)

Brown, L. (1997) Redefining national security. Worldwatch Paper 14, Worldwatch Institute, Washington DC Brown, L. (2003) Plan B: Rescuing a planet under stress and a civilization in trouble. W.W. Norton \& Company, New York 
Brown, L. (2008) Plan B3.0: Mobilizing to save civilization. W.W. Norton \& Company, New York

Central Government of PRC (2011) Decision on ccelerating the water resources reform and development, http://www.gov.cn/jrzg/ (29.3.2011)

Chinanews (2010) Water pricing public hearing to be held in Tianjin, water price will raise 1 yuan per ton, http://www.chinanews.com/ny/2010/08-17/2473050.shtml (20.7.2011)

Dow Water \& Process Solutions (2011) A different look at water: Part I, water for cities and the water-energy nexus. White paper, Dow Chemical Company

Draper, S.E. (ed.) (2006) Sharing water in times of scarcity: Guidelines and procedures in the development of effective agreements to share water across political boundaries. American Society of Civil Engineers, Orlando, FL

Eko-Leder (2011) The Status-quo of development of water resources and major constraints, http://www.eko-leder.com/news/61090.html (20.7.2011)

Healthy Drinking Water Net (2011) Urban household's water saving survey, http://www.51swt.com/wangshangdiaocha/200904/t20090414 868869.htm (20.7.2011)

Ifeng (2011a) Government's monetary policies behave as robbers, people's wealth might melt as ice tubes, http://finance.ifeng.com/news/20101129/2970160.shtml (27.5.2011)

Ifeng (2011b) Desalinized water into Tianjin's scheme water, http://city.ifeng.com/cshz/tj/20110523/92791.shtml (20.7. 2011)

Jackson, T. (2009). Prosperity without growth?: The transition to a sustainable economy. Sustainable Development Commission, London

Kim, J. U. ( 2008) China's water scarcity and hexie shehui (harmonious society). Pacific Focus, 23: 232-251

Li, J. Y., L. J. Li, Y. M. Liu, L.Q. Liang and B. Li (2010) Framework for water scarcity assessment and solution at regional scale: A case study of the Beijing-Tianjin-Tangshan Region. Progress in Geography, 29(9): 19-26

Liu, W., H. Huang, W. Zhang and M. Zhang (2003) Research report on national water efficiency society trialing projects. China Water, 5: B, http://www.wuyin.net/jieshui/pagejsxw27.htm (20.7.2011)

McMahon, P. (2006) Future scenario, On Line Opinion, http://www.onlineopinion.com.au/print.asp?article=4640 (20.7.2011)

Miao, J. J, G.Q. Xiao, H. L. Xie and L. H. Wang (2008) Analysis of water supply structure and countermeasures of Binhai new area in Tianjin city. Geological Survey and Research, 1: 14-17

Ministry of Water Resources of the PRC (MWR) (2002). China water resources bulletin 2001, http://www.mwr.gov.cn/zwzc/hygb/szygb/qgszygb/200212/t20021231_29451.html (10.5.2010)

Ministry of Water Resources of the PRC (MWR) (2010) China water resources bulletin 2009, http://www.mwr.gov.cn/zwzc/hygb/slbgb/201102/t20110212_254486.html (22.7.2011)

Organization for Economic Cooperation and Development (OECD) (2008) Environment outlook 2008. Paris.

Peng, C. Y, J. Zhang, D. Li and Q. Lin (2011) New model of sustainable urban water resource planning: A case study of Sino-Singapore Tianjin eco-city. Journal of Beijing University of Technology, 37, 5: 753-759

Ren, X. S. (2010) A second channel opened to divert water from Yellow River to Tianjin to ease the thirst of Tianjin, http://news.sohu.com/20101024/n276340445.shtml (20.7.2011)

Rijsberman, F. R. (2000) The use of water today, World Water Scenarios: Analyses. Earthscan, London

Sun, J. Y. and J. Zhang (2010) The sustainable development of water resources in Tianjin city. Water Conservancy science and technology and economy, 16(11): 91-93

The Asia Water Project: China (2011), NGOs play a critical role in water conservation, http://www.asiawaterproject.org/for-community/ngos-play-critical-role (22.7.2011)

Tianjin Statistical Information Net (2011a) Bulletin of Tianjin's major data on the 6th national census 2011, http://www.stats-tj.gov.cn/Article/tjgb/pcgb/201105/17511.html (accessed July 18, 2011)

Tianjin Statistical Information Net (2011b). Tianjin City national economy and social development report 2001-2010, http://www.stats-tj.gov.cn (18.7.2011)

Wan, Y. X. and C. Y. Zhou (2009) The goals, challenges and countermeasures for the harmonious development between human beings and water. Yellow River, 31(6): 18-19, 118

Wang, C. (2010) Harbin City's water pricing hearing: A self-entertaining game, http://www.tianya.cn/publicforum/contnet/no06/1/139024.shtml (6.6.2011)

Whiteford, L. and S. Whiteford (eds) (2005) Globalization, water and health: Resource management in times of scarcity. School of American Research Press, Santa Fe, NM

Zhang, Z.B. and P. Xu (2008) Water and food security in China, Chinese Journal of Eco-Agriculture, 16 (5): $1305-1310$

Zhao, H.L. ( 2009) Groundwater development and exploitation problems and countermeasures in Lun river basin and coastal plains of eastern Hebei province. Water Resources Protection, 25(1): 27-29,33

Zheng, T. H. (2003) Water resources safety and water resources safety warning. China Water Resources, 2003-6-A: 19-22 